\title{
Effects of Changes of Lake Victoria Water Levels on Land Use Patterns, Covid-19 Pandemic and Food Security in Winam Gulf, Homa-Bay County, Kenya
}

\author{
Otieno, J. ${ }^{1}$ \& Otieno, A. C. ${ }^{1}$ \\ ${ }^{1}$ Department of Geography and Social Sciences Jaramogi Oginga Odinga University of Science and Technology, \\ Bondo, Kenya \\ Correspondence: Otieno J., Department of Geography and Social Sciences Jaramogi Oginga Odinga University of \\ Science and Technology, P. O Box 210-40601 - Bondo, Kenya. E-mail: otienojohn43@gmail.com
}

Received: November 6, 2020 Accepted: December 12, 2020 Online Published: December 25, 2020

\begin{abstract}
The study was carried out on the Southern shore of Winam Gulf, Homa Bay County, Kenya. It was aimed at establishing the relationship among changes of Lake Victoria water levels, land use patterns and food security during the COVID-19 pandemic. Empirical studies involving ground point survey was used to determine the extent of spread of the back flow and vertical rise of the lake's waters from five pier and nine beach survey points between July 2019 to October 2020. In-depth interviews and questionnaires were also used to collect data which were analyzed using descriptive statistics and Likert's scale. The average variations of the extent of the back flow was approximately $294 \mathrm{~m}$ while the vertical change in the water levels along the pier points was $1.03 \mathrm{~m}$. This led to submergence of the adjacent land use patterns and interfered with food security in the region. Coupled with the impacts of COVID-19 pandemic, majority (209) of the respondents substituted their meals and a quarter (79) of the them reduced their number of meals per day. A strong positive perception on the responses by the Government of Kenya and County Government Homa Bay towards addressing the pandemic with the Likert's scale summative perception index of 381 very effective, 328 effective and 363 satisfactory were realized. The study recommends: observance and execution of environmental laws governing settlement on riparian lands, proactive compliance with the warnings and advice from the meteorological department, and adoption of alternative land use patterns.
\end{abstract}

Keywords: back flow, COVID-19 pandemic, food security, land use pattern and recession

\section{Introduction}

Corona Virus Disease (COVID-19) is the latest global pandemic threatening the social, economic and political spheres of life. The disease's epicenter was in Wuhan, China in December, 2019 and spread to other parts of the world. Coincidentally, it was the same period that various lakes in the world experienced rise in their water levels causing flooding of their adjacent shoreline. Such lakes included the Great Lakes (Capital Weather Gang Analysis, 2019), Lake Kyoga, Albert and Victoria (NBI, 2020), Rift valley lakes of Kenya (Robi, 2020).

Recession of the waters of Lake Victoria has been beneficial to the local community through provision of more land for agriculture, sand excavation, settlement, grazing and papyrus reeds used for weaving mats (Obiero et al., 2012). However, the current back flow and flooding phenomena on the lake shores have reversed these gains and caused destruction of properties, loss of biodiversity and displacement of people in the region despite existence of environmental laws governing settlement on riparian lands. The impacts of the lake's back flow and consequent flooding coupled with the impacts of the COVID-19 pandemic exerted enormous strain on food availability, accessibility and sustainability causing double crisis. Hence, the need for ad vocation for adherence to laws governing settlement along the shoreline in order to reduce the impacts of damages caused by occurrence of such phenomena in future.

The current changes in the Lake Victoria water levels is a unique phenomenon that has only been witnessed twice in historic time: 1964 and 1997/98 (Nicholson, 1998/99 and NBI, 2020). Thus, the current occurrence provides an opportunity to have accounts of its effects for future references. Additionally, most studies on the changes of the Lake Victoria water levels have mainly concentrated on recession (Ogola et al., 1997; Aloo, 2002; Obiero et al. 2012, Otieno and Otieno, 2019) and paid less attention to back flow effects. Hence, this study aims at bridging this gap. 
Food security is an important pillar in the big four agenda of the Jubilee government of Kenya, Kenya's Vision 2030 and Global Food Security 2030 (FAO 2012; Kenya Vision 2030). However, disruption of land use patterns due to flooding caused negative impacts on the achievement this goal. Thus, the need for evaluation of new land use patterns and activities to promote food availability, accessibility and sustainability in Homa Bay County which has the longest shore line stretch within Winam Gulf Counties of Kenya.

Lake Victoria is among other lakes in the world that have been experiencing alternation in the levels of their waters in historical time. Such lakes include: The Great Lakes in U.S.A (Capital Weather Gang Analysis, 2019), Rift Valley lakes in Kenya (Ogola et al., 1997; Why Rift Valley lakes, 2020; Robi, 2020), Lake Kyoga and Albert, (NBI, 2020), Lake Okeechobee in U.S.A, (Steinman et al., 2002), Tulare Lake of California (Tulare Lake Basin n.d), Aral Sea in Russia (Gaybullaev and Gaybullaev, 2012), Lake Chilwa in Malawi (Nagoli et al., 2017).

Lake Victoria has been experiencing alternating periods of recession and back flow (flooding) over time. Records of the alternation of the changes of the lake's water levels from 1950 to date with the lowest water level being recorded in 1952 are provided by (Kite, 1982; Nicholson, 1988; Okonga et al., 2005; LVBC, 2006). The sharpest rise in the lake's water levels before 2020 occurred during the El'Nino rains of early 1960s and 1997 and 1998 (Nicholson, 1998 and 1999). This caused a rise in the lake's waters by 2.5m in 1964 (Aseto and Ong'ang'a, 2003; Kite, 1991; NBI, 2020) which was the highest rise up to 2020.

The lake's water levels have been on the decline since 1964 except in 1982 and 1997/98 when it reached a minimum of $10.4 \mathrm{~m}$ in 2006 (USDA 2OO5; NBI, 2020). The 2019/20 enhanced rainfall saw a historical increase of the waters of Lake Victoria from 13.41m in 1964 to 13.42m in May, 2020 (NBI, 2020). However, the lateral extent of the lake's waters expansion into the shore land is missing from the NBI, 2020 report. In 2006 the water levels fell to its lowest height of 10.4m (USDA 20O5; Crisis Looms as Lake Victoria Shrinks, 2006). In May 2020, it rose to its historic height of $13.42 \mathrm{~m}$ surpassing the 1964 rise by $0.1 \mathrm{~m}$ (NBI, 2020). This implies that the Lake Victoria water levels rose by $3.2 \mathrm{~m}$ by May 2020 .

Recession of the waters of Lake Victoria provided more land for expansion and establishment of various land use patterns such as agriculture, grazing, trade, settlement, sand extraction, papyrus reed and transportation (Obiero et al., 2012). These land use patterns positively contributed to food security. However, the falling of the lake's waters reduced fishing grounds (Obiero et al., 2012) hence, reduced fishing activities and negatively contributed to food security. Nevertheless, the recession was succeeded by back flow and flooding phenomena from 2019 to 2020 . The local community argued that the lake was reclaiming back it original land left behind due to recession that occurred after the uhuru rains of 1960s and the 1997/8 El Nino rains. The study was guided by the following specific objectives: To find out the variations of the extent of the back flow of the Lake Victoria waters levels between July 2019 to October 2020. To assess the impacts of the changes of the Lake Victoria water levels on land use patterns. To examine the responses of the local communities living on the lake shores to the back flow and COVID-19 pandemic and to investigate the impacts of the changes of the Lake Victoria water levels and COVID19 pandemic on food security on the Southern shores of Winam Gulf, Homa Bay county, Kenya.

\section{Methodology}

The study was carried out in the Southern shores of Winam Gulf, Homa-Bay County, Kenya (Figure 1). It encompassed the lake shores of three Sub-Counties namely Rachuonyo North (Karachuonyo), Rangwe and Homa Bay (Figure 2). These areas were randomly chosen to represent the entire Winam Gulf and Lake Victoria at large. 


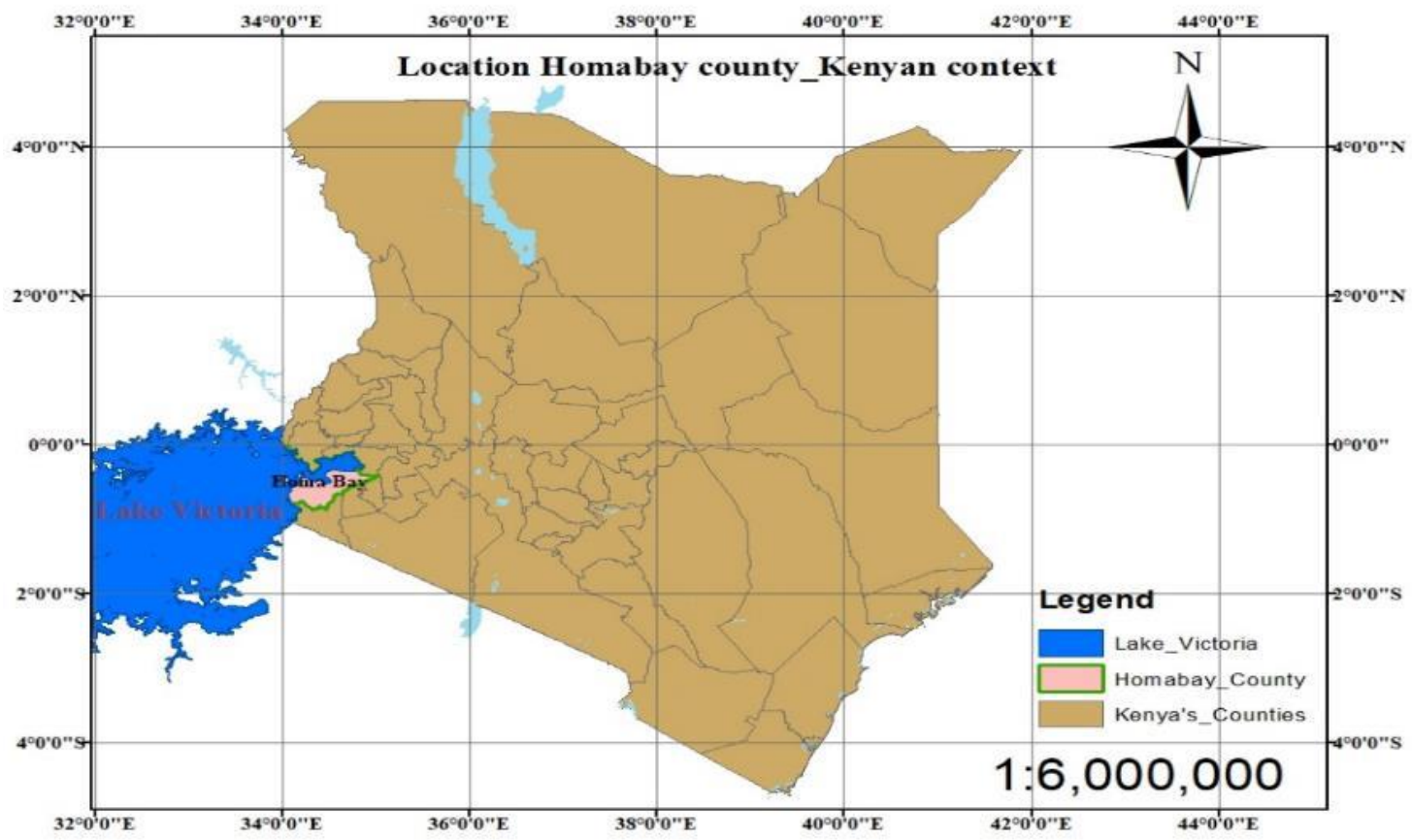

Figure 1. Map showing the location of Homa Bay County in Kenya

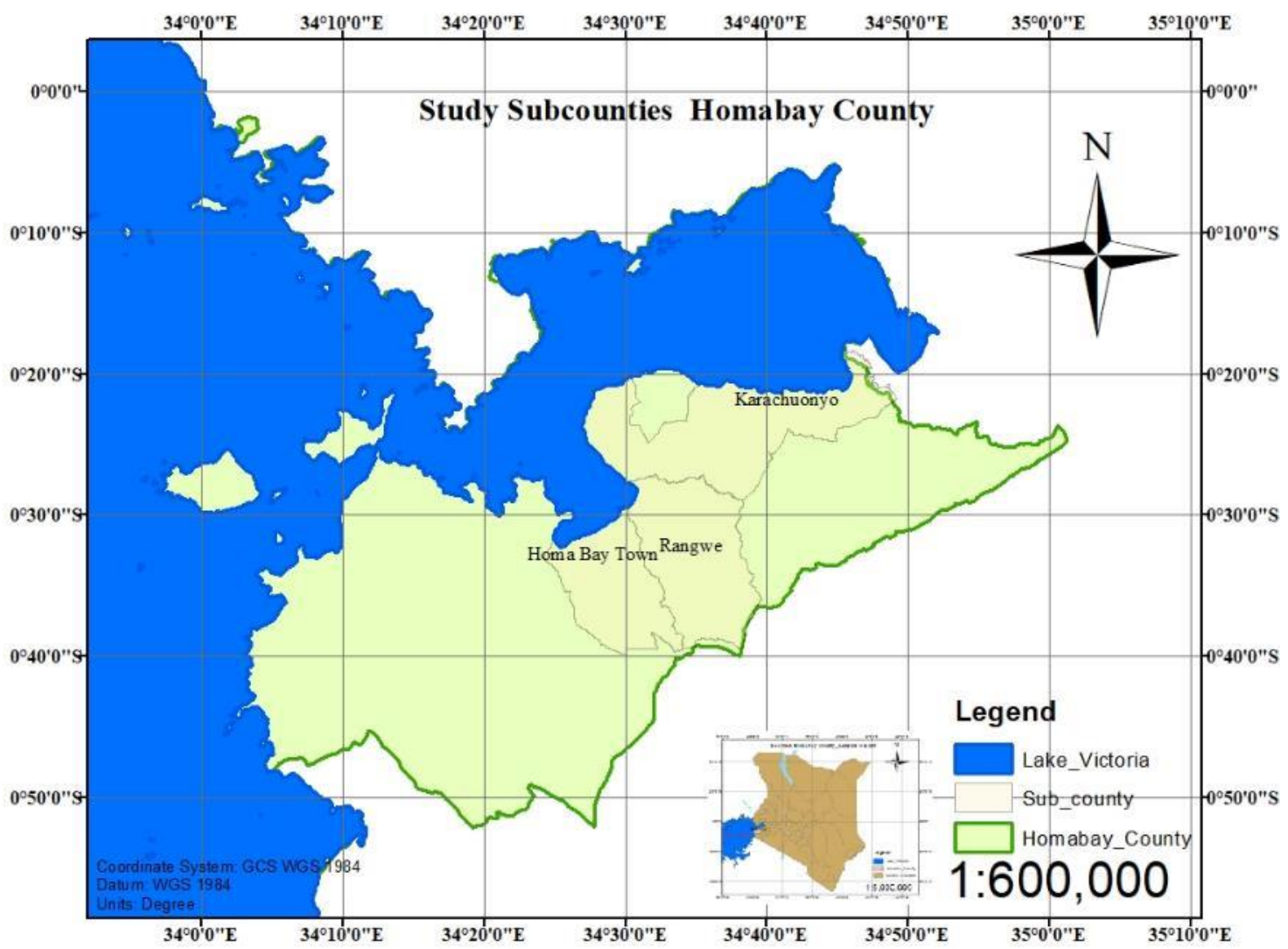

Figure 2. Map showing the study Sub-Counties of Rachuonyo North (Karachuonyo), Rangwe and Homa Bay

The study used cross sectional survey design as it was carried out at a given spatial time between July, 2019 to October, 2020. All land users along the study area were targeted. A sample size of 384 respondents was picked randomly for the study. This was obtained using Smith, (2013) formulae for calculation of sample sizes for 
unknown population as there was lack of documented population data for the study area. The study used: Confidence level $=95 \%$, standard deviation $=0.5$ and margin of error $=+/-(0.5)$. Thus;

$$
\begin{aligned}
\text { Sample size }(\mathrm{s})= & (\mathrm{Z} \text { score })^{2} \times \text { Standard Dev. } \times(1-\text { Std Dev }) \div(\text { Margin of error })^{2} \\
& \mathrm{~s}=\left[(1.96)^{2} \times 0.5(0.5)\right] \div(0.5)^{2} \\
& \mathrm{~s}=(3.8416 \times 0.25) \div 0.0025 \\
& \mathrm{~s}=0.9604 \div 0.0025 \\
& \mathrm{~s}=384.16 \\
& \mathrm{~s}=384 \text { respondents }
\end{aligned}
$$

The qualitative data used were on land use patterns such as: settlement, crop farming, grazing, sand extraction, fishing, trade, transportation, fallow/wetland/papyrus reeds and recreation. The quantitative data were on fish catch quantity and prices as well as changes on the sizes the land use patterns.

The study mainly relied on primary data which were collected through: direct field observation, in-depth interviews of the direct shore land users (e.g fishermen, farmers, traders, settlers, craft makers, herdsmen e.t.c), administration of questionnaires, point measurement of the variations of the height of the water levels at pier points and lateral spread of lake waters into the land surface using hand tape measure and surveyor's foot measure. Point measurements were done using ground physical survey from specific study points throughout the study period.

The first survey points were sited at five pier points where the vertical variations of water levels at the pier sides were determined using a hand tape measure between July 2019 and October 2020. Three out of the five study points were sited at the sides of the main piers at Kendu-Bay, Kowuor and Homa-Bay piers. The other two study points were located on the small boat landing piers located at Achuotho beach near Kendu-Bay and on the Capital Fish landing pier next to Homa-Bay main pier.

The heights of the five piers were measured regularly from the top of the piers' rail guards exposed over water. The original measurements of the heights of the hanging pier's side rail guards were taken as from July, 2019 and recorded. Subsequent measurements, readings and recording of the changes of the heights of the rail guards were carried out regularly until the end of the back flow which was characterized by plateauing of flooding of the shore land and gradual retreat of the lake waters. The Changes in the Level (CL) of the lake's waters were obtained by subtracting the average New Minimum Overhanging Height (NMOH) from the Original Overhanging Height $(\mathrm{OOH})$ of the rail guards at the side of the piers. That is; $\mathrm{CL}=\mathrm{OOH}-\mathrm{NMOH}$. The measurements were taken at different positions (sides of the large piers and on top of small low-end piers) (Figure 3) so as to corroborate and authenticate the findings.

Lateral spread of the back flow was defined as the horizontal distance on the ground under flooding by the lake's waters. It was determined from nine survey points (Figure 3) located at different elevations on the shore line using point measurement with the aid of a surveyor's foot measure. The research relied on physical land marks before the back flow such as mangrove and other trees species and human made features like abandoned boats, steamers and buildings at the point where water levels reached during the last recession. From these points, measurements, readings and recording of the spread of the back flow and flooding of the shore were taken. Other aspects of data that were obtained from the respondents through interviews and questionnaire administration were analyzed using descriptive statistics and Likert's Scale 1-5 based on Effective Perception Index (EPI) and Summative Effective Perception Index (SEPI). 


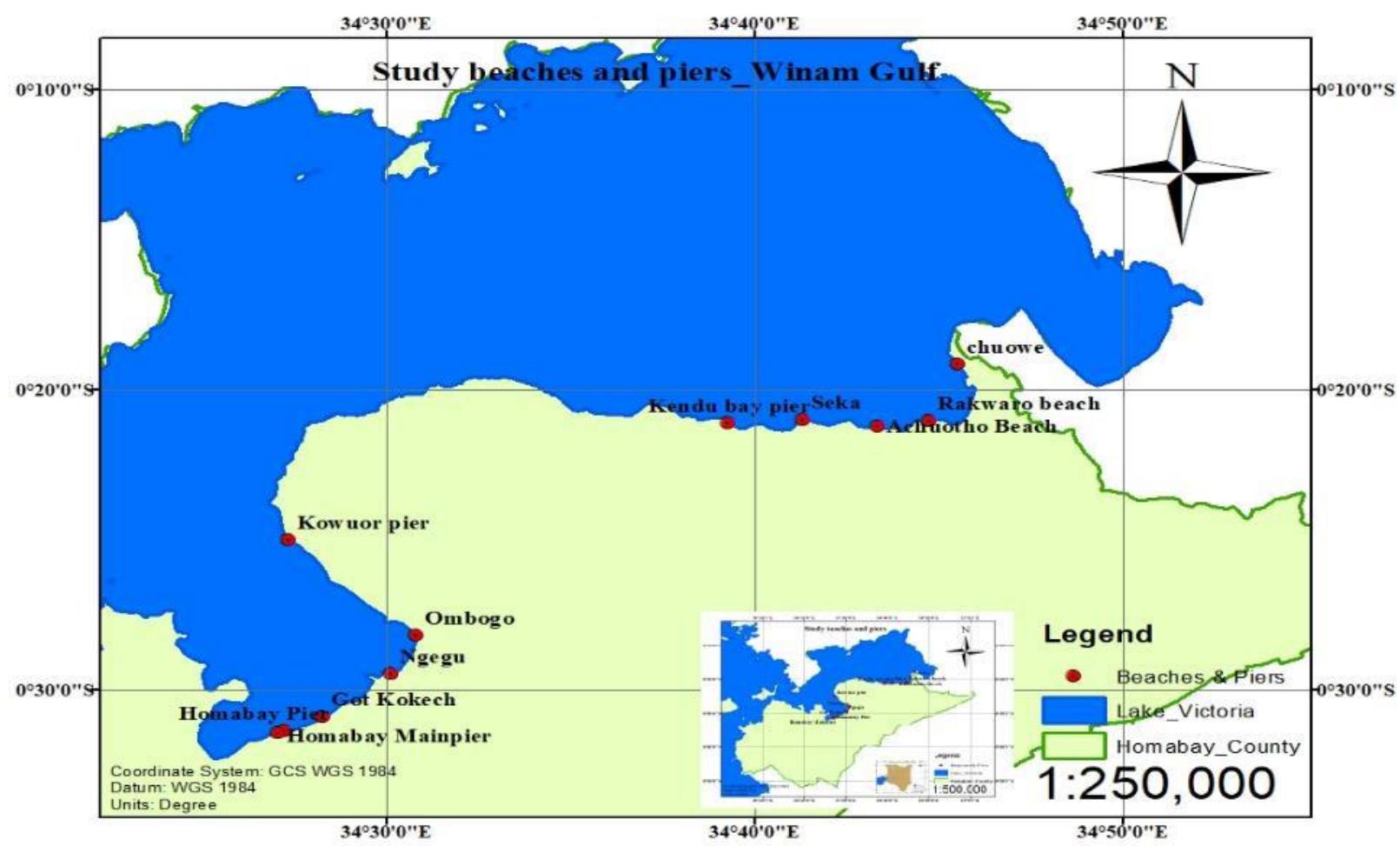

Figure 3. Map showing the location of the data collection points for the study

\section{Results and Discussion}

The rise in levels of the Lake Victoria waters led to submergence of the two small piers at Achuotho beach and Capital Fish pier in Homa Bay town. This hindered accurate data collection from such sites. Hence they were not included in the final analysis of the resultant data. Changes of water level at the remaining three survey points are tabulated as follows:

Table 1. Changes in the overhanging heights $(m)$ of the piers' rail guard $(n=3)$

\begin{tabular}{|l|l|l|l|}
\hline Survey points & Original overhanging height $(\mathrm{m})$ & New overhanging height $(\mathrm{m})$ & Change in height $(\mathrm{m})$ \\
\hline Kendu Bay pier & 1.6 & 0.6 & 1.0 \\
Kowuor/Homa Lime pier & 1.2 & 0.2 & 1.0 \\
Homa Bay pier & 1.4 & 0.3 & 1.1 \\
\hline Average & 1.4 & 0.366 & 1.033 \\
\hline
\end{tabular}

Table1, showed that the levels of the rise of Lake Victoria waters was approximately $1.033 \mathrm{~m}$ between July 2019 to October 2020. Initially, the three piers had different heights exposed over water with an average of $1.4 \mathrm{~m}$. The average new height of the piers exposed over water was $0.366 \mathrm{~m}$ after the study giving an average rise of water level to1.033m. 
Table 2. Extent of the lateral spread of the back flow on the Southern shore of Winam Gulf, Homa Bay County $(\mathrm{n}=9)$.

\begin{tabular}{|c|c|c|c|}
\hline Beaches / shore line & Extent of back flow (m) & Beaches / shore line & Extent of back flow(m) \\
\hline Chuowe & 271 & Ombogo & 500 \\
\hline Rakwaro & 180 & Ngegu & 355 \\
\hline Seka & 192 & Got Kokech & 300 \\
\hline Kendu Bay & 128 & Homa Bay & 55 \\
\hline Kowuor Lime & 77 & Average $=294 \mathrm{~m}$ & \\
\hline
\end{tabular}

Source: Researcher, (2020). Kindly delete

Data on Table 2 succinctly showed an average of $294 \mathrm{~m}$ lateral spread of back flow and its consequent flooding of the shore line. Homa Bay and Kowuor beaches had the shortest extent of back flow at $55 \mathrm{~m}$ and $77 \mathrm{~m}$ respectively due to their nature of the shoreline which were slightly emerged. Ombogo and Ngegu beaches had the longest extent of back flow and consequent flooding at $500 \mathrm{~m}$ and $355 \mathrm{~m}$ respectively. This was attributed to their adjacent peneplain shore line which allowed water from the lake to easily flow back to the land and caused flooding. The large area under flooding with average width of $294 \mathrm{~m}$ (Table 2) of submerged land thwarted food security in the region. Empirical studies in addition to interview data obtained from the respondents on the change of size of land use patterns due to back flow of the Lake Victoria waters from May 2019 to October 2020 is provided in Table 3.

Table 3. Respondents views on the changes in land use patterns on the Southern shores of Winam Gulf before May 2019 and after May 2019 to October $2020(n=384)$

\begin{tabular}{llll}
\hline Land use pattern & \% Reduction & \% Same & \% Increase \\
\hline Crop farming & 100 & 0 & 0 \\
Fishing & 29 & 12 & 59 \\
Grazing & 97 & 0 & 3 \\
Sand excavation & 95 & 0 & 5 \\
Papyrus reeds & 12 & 0 & 88 \\
Settlement & 99 & 0 & 1 \\
Trade & 64 & 35 & 1 \\
Transport & 78 & 20 & 2 \\
Recreation & 90 & 6 & 4 \\
\hline
\end{tabular}

From Table 3, nearly all land use patterns reduced in sizes except fishing grounds and papyrus reeds. This was contrary to the findings by Obiero et al. (2012) who found out that fishing ground was the most reduced land use activity in Winam Gulf, Nyando wetland during recession. The reduction in land sizes under the mentioned land use activities (Table 3) threatened food security in the region. The reduction in size of the crop land thwarted food availability in the region since most of the local residents depended on food crops such as kales, tomatoes, onions, maize, sorghum among others that were grown along the shore. Such locally produced crops were cheaper as compared to those imported from other areas. Coupled with the COVID-19 pandemic which greatly affected the world's economy (World Bank Report, 2020), access to food was revealed as a major challenge.

Nearly all the respondents $(97 \%)$ asserted that grazing land was severely reduced by the back flow and its resultant flooding of the shore line causing submergence of pasture (Table 3). Consequently, wild life such as hippopotamus fringed their periphery and attacked human beings in their homes and farms along the shore forcing people to migrate. Emigration denied the locals opportunity to constructively engage in economic activities that boosted food security. Thus settlement patterns along the shore were affected as many (99\%) beach centers and homes adjacent to the old shore line were deserted. Hence, compliance with the environmental laws governing settlement of at least $200 \mathrm{~m}$ from the lake would have saved the situation (Apunyo, 2006). 


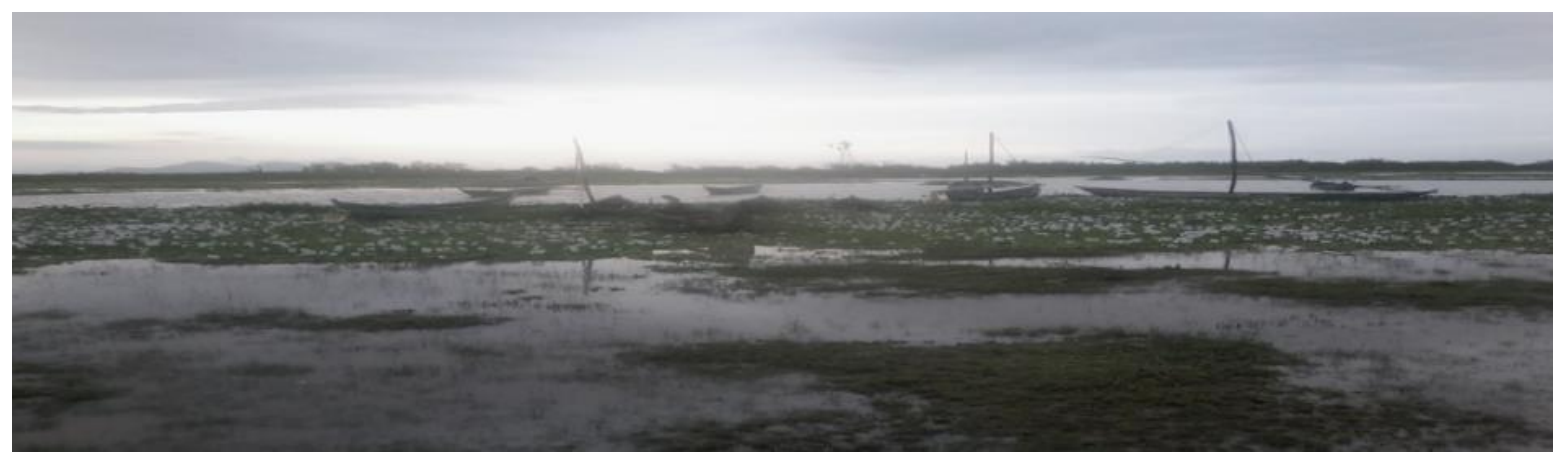

Plate 1. Change of land use pattern from grazing land to fishing/beach by March, 2020

The land use activity shown in Plate 1 is currently fishing but was previously a grazing land before the back flow phenomenon.

Many (95\%) respondents lost their sand excavation sites to back flow and were forced to either abandon the activity or shift to other areas away from the shore line. Hence, they lost source of income needed to purchase food. Coupled with the stay at home call to reduce the spread of COVID-19 pandemic, attempts to engage in other economic activities to earn income to buy food were hindered. Consequently, access to food was a challenge.

Area under aquatic weeds (papyrus reed and hippo grass) was reported by (88\%) to have expanded (Table 3 ) consuming the land which was previously under crop farming, grazing or sand exaction as shown in Plate 2 . This encouraged craft industry as the reeds were used to make mats for sale. However, due to economic hardship brought about by effects of COVID-19 pandemic, there was low demand for mats affecting cash flow required to purchase food leading to food insecurity.

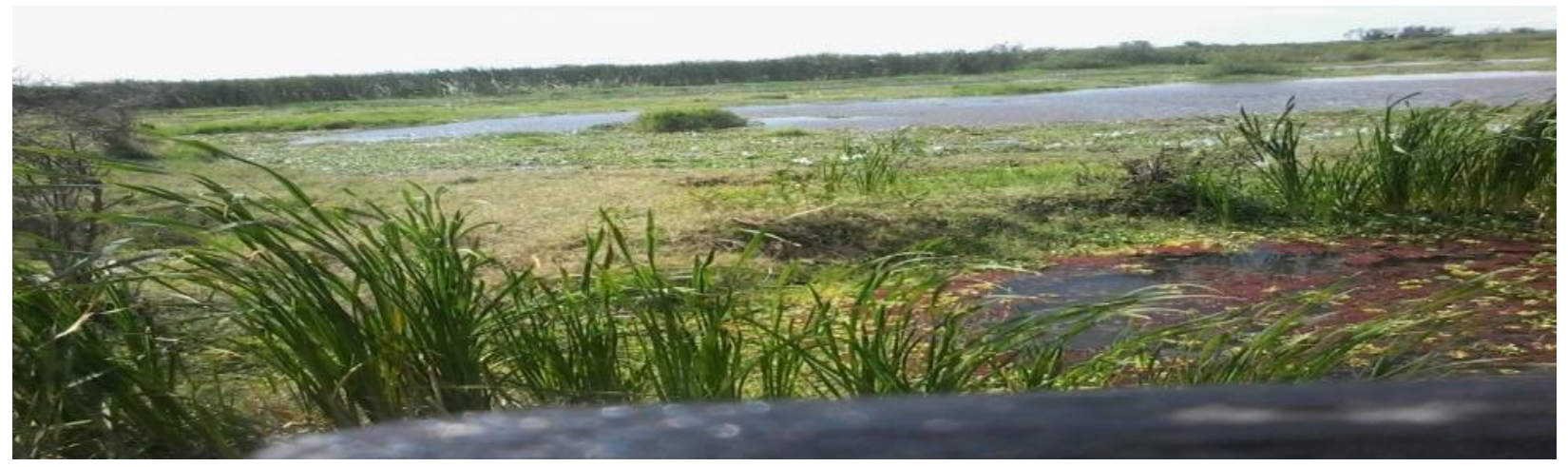

Plate 2. Change of land use pattern from farming and sand excavation to papyrus reeds vegetation during back flow by October, 2020

The emergence of vegetative cover along the shore line blocked fishing beaches causing accessibility and docking challenges to fishermen.

More than two thirds $(64 \%)$ of the respondents revealed that trade activities reduced (Table 3 ) because of the back flow and ban on open markets by the CGoHB to curb the spread of COVID-19 pandemic. As a result, people kept off markets and other social places in fear of contracting the virus. The overall impacts of these measures on food security was dire as it disrupted cash flow deeded to access food.

More than three quarters ( $78 \%$ ) of the respondents (Table 3) reported destruction of transport infrastructure along the shores of the lake. Empirical studies showed that some roads and foot paths along the shore were completely submerged while others were cut off in the middle by the infringing the (delete) lake's waters. These interfered with land use patterns as paths and roads had to be made on new lands where they were non-existent. Consequently, Transporters had to make detours to deliver goods resulting to scarcity and increase in prices of goods and food. Araoye et al. (2016) also had a similar finding in Nigeria. 
A large number of the respondents (90\%) revealed that recreation activities were affected (Table 3) due to erosion of the main piers at Kowuor and Homa Bay and submergence of minor piers at Achuotho beach and Homa Bay minor pier for Capital Fish company. Other beaches which were used for swimming were abandoned due to inaccessibility problems. Consequently, some water pans left after sand excavation and filled with the back flow water were used for swimming purposes instead.

More than half (59\%) of the respondents reported that fishing as a land use activity increased during the back flow period (Table 3). This was due to expansion of fishing ground due to back flow and flooding of the shore land. However, more than a quarter (29\%) of the respondents contradicted this revelation by stating that fishing activity reduced where as $12 \%$ of the respondents were neutral (Table 3 ). This was attributed to low amount of fish caught during the back flow resulting from destruction of the fish breeding grounds by the rising water levels. Since fish is a staple food for the Luo community who inhabit the region, its shortage led to hike in prices beyond reach by many residents. Hence access to fish was a challenge. Nevertheless, Rehm et al. (2011) assert that the increase in prices will have less impact on demand for staple food such as cereals. Unfortunately, the local community could not resort to cereals due to the destruction of crops in the field and transport network which impeded importation of food from other areas.

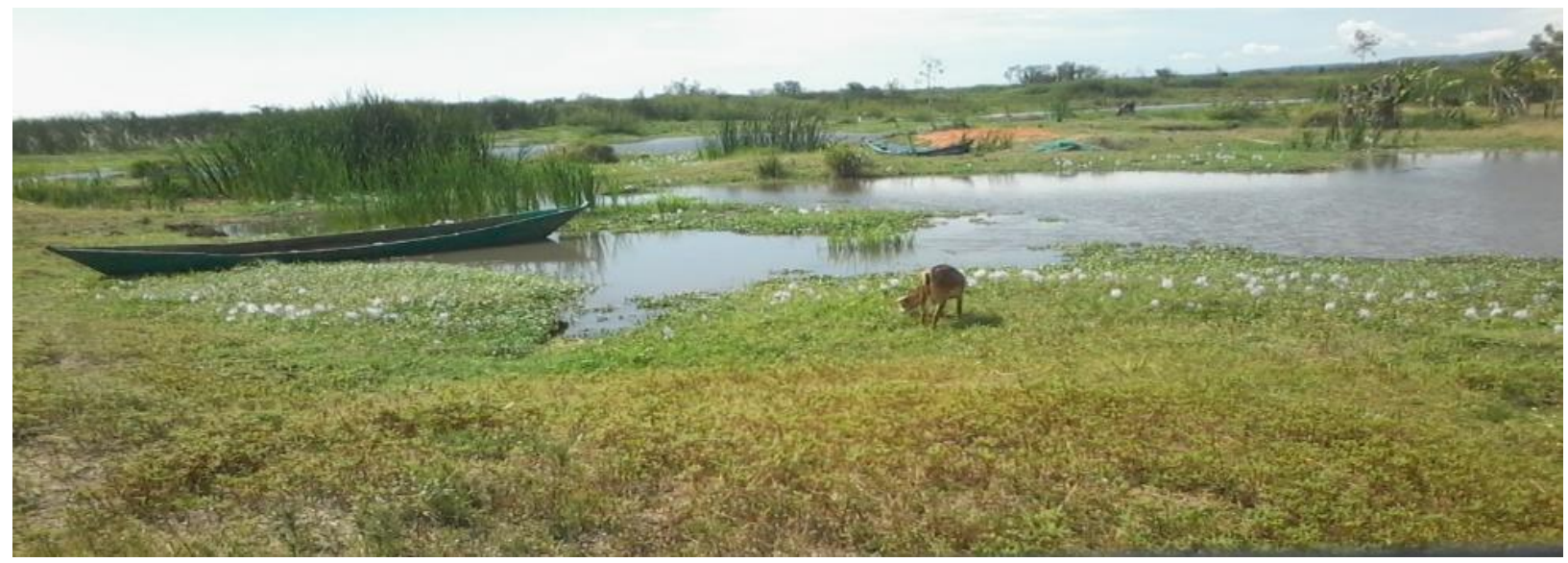

Plate 3. Mixed land use pattern caused by back flow

In Plate 3, the lake is in the dead ground 200m away and is blocked by vegetation in the background. In the center midle ground, lies boats and a fish net indicating fishing activity in the area. In the right middle ground of Plate 3.3, are banana crops while in the center foreground is a goat grazing. Water bodies in the middle ground were previously sand excavation sites before the back flow.

Nevertheless, after May, 2020, water levels began to retreat gradually and some parts of the shore which were deserted during the peak of the back flow were resettled. Plates 4 (a) and (b) explicitely show the change of water levels and land use patterns during the peak of the back flow in May, 2019 and afterwards in October, 2020 in one of the shore lines. 


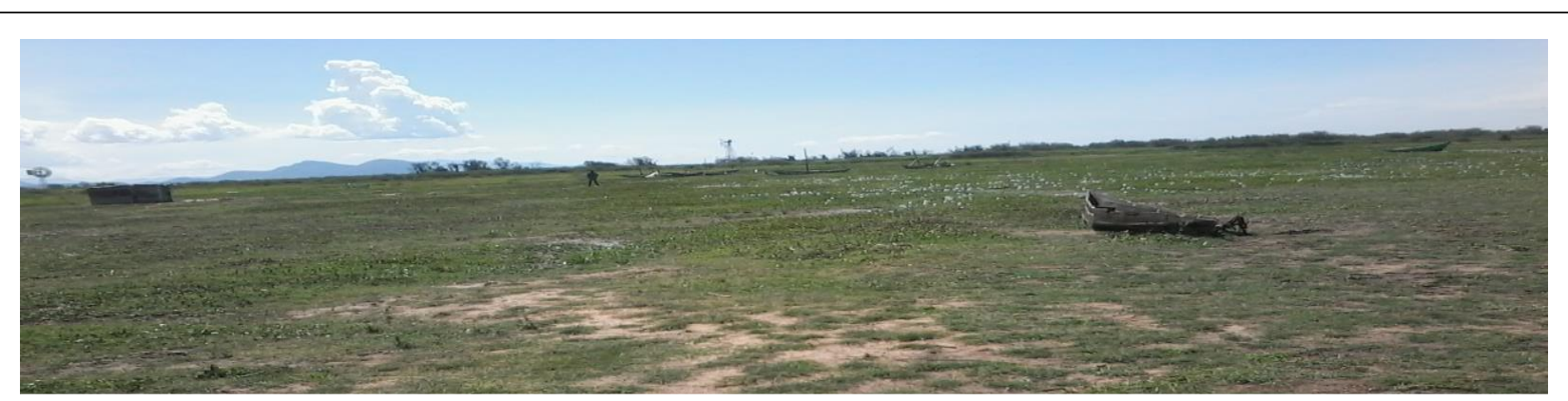

a) Peak of the back flow by March, 2020 .

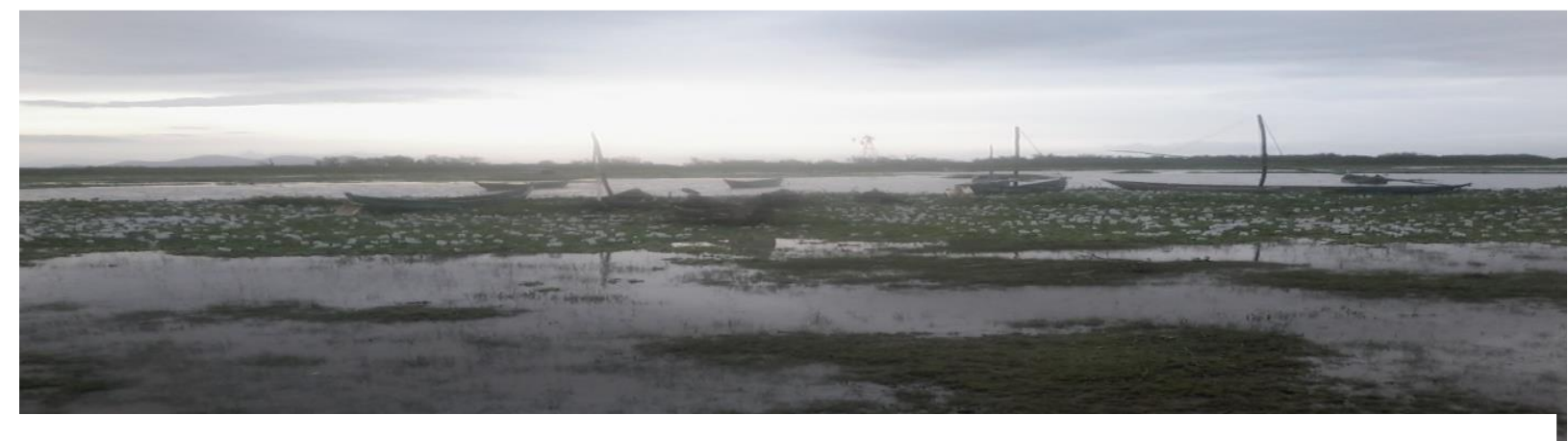

b) Recession of the back flow by October, 2020 .

Plates 3.4( $\mathrm{a}$ and $\mathrm{b})$ : Gradual changes of land use patterns from fishing (beach) back to grazing land

Source: Researcher, (2020) kindly delete. Seven months after the peak of the back flow and consequent flooding of the shores of Winam Gulf, near Ombogo beach (Plate3.4b). Water level receded and the original land use activity (grazing land, Plate $3.4 \mathrm{~b}$ ) was gradually reclaiming its place. Fishing activity (beach) declined as water level reduced and boats could not anchor (Plate 4b), hence the boat owners shifted to other beaches except the few boats shown in the middle ground of Plate $4 \mathrm{~b}$. At this survey point, the lake's waters had receded by approximately $100 \mathrm{~m}$ from May, 2020 when it was at its maximum width of 500m (Table 2). In the Plates 4 (a and b), the main lake is in the dead ground on the left side.

In regards to food prices in the area, fish being the staple food for the local community, was picked for comparison of prices before and during the back flow and COVID-19 pandemic periods. Omena (Silver Cyprinid) was chosen for the study because of its low prices as compared to other fish species in the region. Table 3.4 summarizes the prices of Omena at various markets before and during the back flow and COVID-19 pandemic crises.

Table 4. Average prices of Omena (Silver Cyprinid) per koro koro at various markets along the Southern shores of Winam Gulf, Homa-Bay county, Kenya before and during the back flow and COVID-19 pandemic ( $\mathrm{n}=6$ )

\begin{tabular}{llc}
\hline Markets & Prices(Ksh.) before back flow \&COVID-19 & Prices(Ksh.) after back flow \&COVID-19 \\
\hline Nyakwere & $200-250$ & $300-350$ \\
Kendu-Bay & $200-260$ & $300-350$ \\
Oriang & $200-250$ & $300-350$ \\
Nyangweso & $180-250$ & $300-340$ \\
Pala & $200-250$ & $300-350$ \\
Homa-Bay & $300-350$ & $350-400$ \\
\hline
\end{tabular}

Table 4 showed that the prices of koro koro ( $2 \mathrm{~kg}$ container of cooking fat) of Omena increased by a margin of 50 Kenya shillings (0.51 US Dollars) in nearly all the markets. The surge in price was attributed to the scarcity of Omena due to low catch occasioned by the rise in the Lake Victoria water levels and increase in transport cost of the commodity due to COVID-19 pandemic effects. With the rise in the prices of Omena and decline in per capita 
due to COVID-19 pandemic effects, access to food was a challenge among many households. This is because purchasing power and eating behavior of a people is affected by the rising food prices (Mkhawani et al., 2016). The changes in the Lake Victoria water levels altered land use patterns in the region. Therefore, the local communities had to cope with the changes in land use patterns as shown in Figure 4.

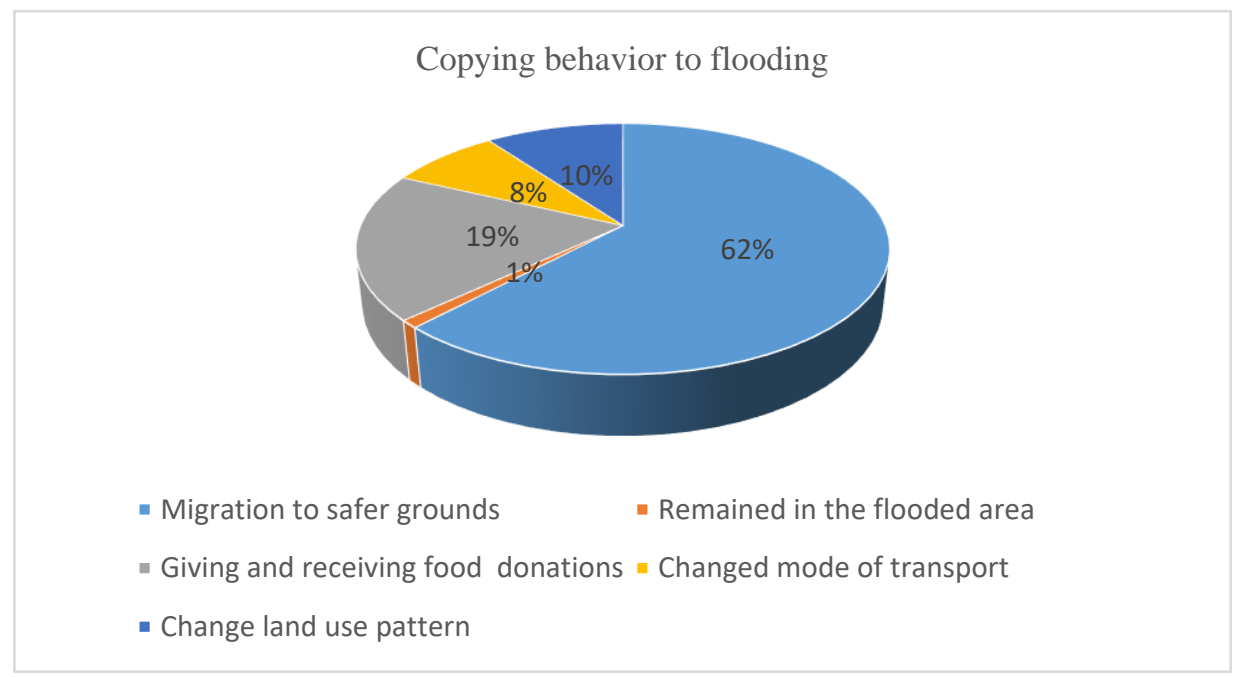

Figure 4. Copying behavior of the respondents to the back flow and flooding

Figure 4 explicitly showed that majority (62\%) of the respondents migrated to safer grounds to avoid flooding. The study found out that the migration to safer areas assumed three different destinations namely: churches and schools located on the higher grounds, settling in nearby local centers and staying with their relatives away from the flooded areas. However, in the safer higher grounds, the flood evictees stayed in fear of contacting the COVID-19 pandemic which was against social gathering and close contact. This resulted to double crisis as it was unsafe to stay in the source areas due to flooding and also in the destination areas in groups.

The second largest portion (19\%) of the respondents showed philanthropy by giving food donations to the victims of flood while the third largest portion (10\%) reported to have changed land use patterns Figure 4 . The second smallest portion (8\%) of the respondents changed their mode of transport (Figure 4) as use of boats became a new form of transport in some areas which were previously land surfaces. The smallest portion (1\%) of the respondents stayed put in the flood affected areas. In all these situations, access to food and food availability was reported to be a major problem.

Besides the responses to the back flow and flooding phenomena, the local inhabitants had to simultaneously cope up with the ravaging impacts of COVID-19 pandemic. Figure 5 records the community's responses to the COVID19 pandemic.

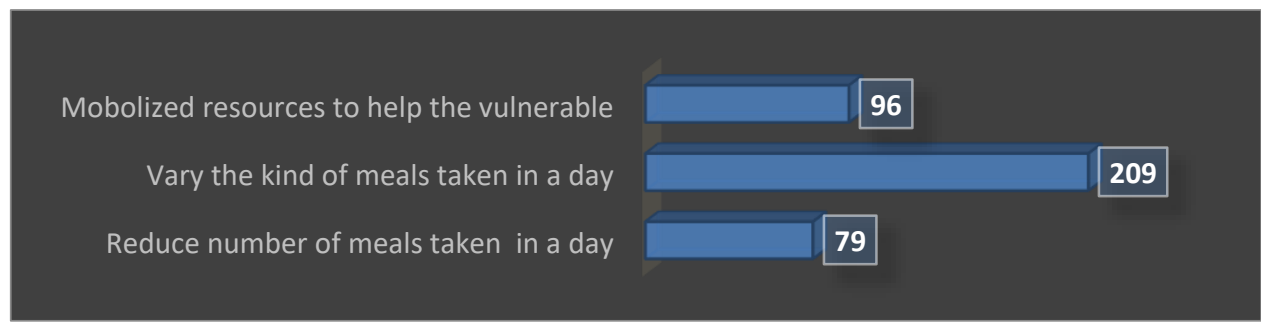

Figure 5. The local communities' responses to COVID-19 pandemic

From Figure 5 it is succinct that majority (209) of the community members varied the kind of meals they took in a day. The respondents revealed that ugali (cornmeal mush) being the staple food was substituted with other lighter and cheaper meals such as tea, chapati (flat bread) or porridge. 
Some respondents (96) asserted that they reduced the number of meals taken in a day (Figure 5). This was attributed to reduction in income to access food as a result of the impacts of the pandemic and floods. The destruction of locally grown food by floods couple with disruption of transport network in the region caused food availability problems. A few (79) respondents revealed that resources were mobilized by professional and business members of the community to support the needy in the society (Figure 5). Thus, the pandemic saw an increase in philanthropism among the local community. Besides the local communities' response to the double crisis, both the county government of Homa Bay and the national government of Kenya also played crucial roles to save the situation as shown in Figure 6.

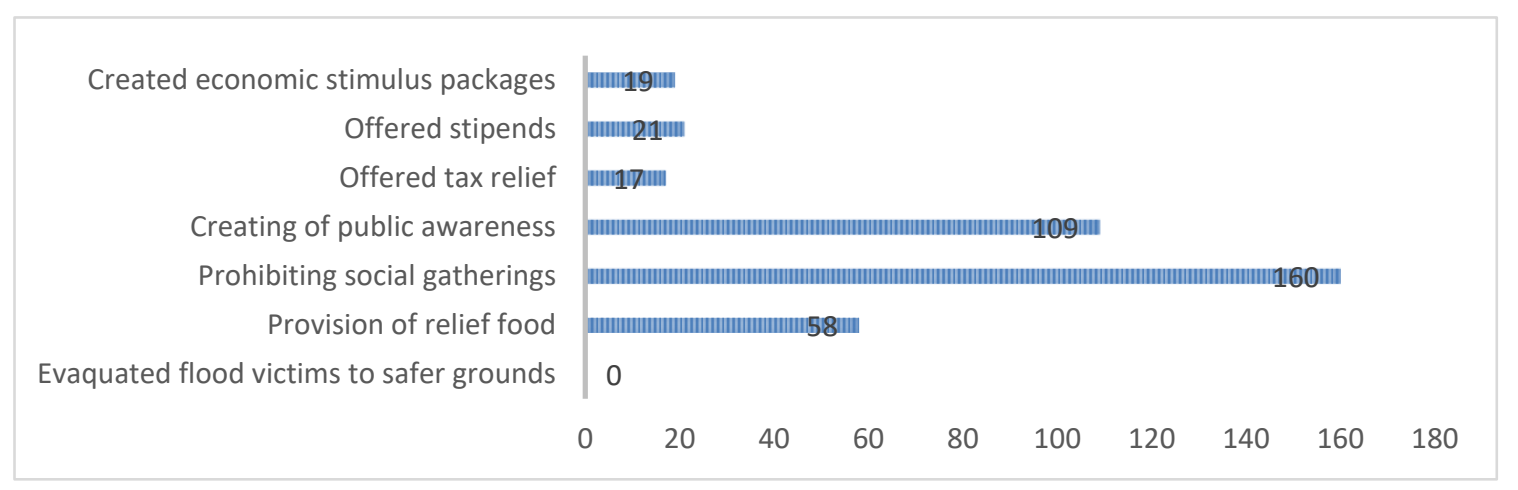

Figure 6. Response by the county and national government to the double crisis

From Figure 6, majority (160) of the respondents revealed that prohibition of social gathering was the most outstanding role done by the two levels of government to curb the spread of COVID-19 pandemic. In this regard, social amenity sites such as churches, schools, markets, bars, hotels, sand extraction sites and restaurants except health centers were closed and reinforced by imposing night curfews. Public awareness creation was the second best (109) cited measure taken to curb the spread of the COVID-19 pandemic in particular. This was done through both local and national media stations. There were no evacuations in the area (0), however, relief food was provided to some (58) respondents who fell victims of flood eviction and displaced to schools and churches in the higher grounds.

Creation of economic stimulus packages by the GoK through Kazi Mtaani program had 19 responses, offering of stipends through a special fund for the elderly had 21 responses while offering tax relieves through reduction of Pay as You Earn (P.A.Y.E) and Value Added Tax (V.A.T) had 17 responses (Figure 6).

Table 5. Perceptions of the local communities on the response towards handling of the flood and COVID-19 phenomena (double crisis) by the GoK and CGoHB

\begin{tabular}{|c|c|c|c|c|c|c|c|c|c|c|}
\hline \multirow[t]{2}{*}{ Response to the double crisis } & \multicolumn{2}{|c|}{ Very Effective } & \multicolumn{2}{|c|}{ Effective } & \multicolumn{2}{|c|}{ Satisfactory } & \multicolumn{2}{|c|}{ Not Effective } & \multicolumn{2}{|c|}{ Neutral } \\
\hline & EPI & $\%$ & EPI & $\%$ & EPI & $\%$ & EPI & $\%$ & EPI & $\%$ \\
\hline Creating economic stimulus packages & 44 & 22 & 52 & 26 & 101 & 50.4 & 0 & 0 & 3 & 1.5 \\
\hline Offering stipends & 48 & 24 & 56 & 28 & 90 & 45 & 0 & 0 & 6 & 3 \\
\hline Offering tax relief & 49 & 24.5 & 69 & 34.5 & 74 & 37 & 2 & 1 & 6 & 3 \\
\hline Creating public awareness & 150 & 75 & 40 & 20 & 10 & 5 & 0 & 0 & 0 & 0 \\
\hline Prohibiting social gatherings & 70 & 35 & 90 & 45 & 18 & 9 & 0 & 0 & 2 & 1 \\
\hline Provision of relief food & 20 & 10 & 21 & 10.5 & 70 & 35 & 0 & 0 & 89 & 44.5 \\
\hline Evacuating flood victims to safer grounds & 0 & 0 & 0 & 0 & 0 & 0 & 160 & 60 & 40 & 20 \\
\hline SEPI & 381 & & 32 & & 363 & & & & 146 & \\
\hline
\end{tabular}

The SEPI of 381 very effective and 328 effective (Table 5) showed a strong positive perception the respondents had on the response by the two levels of government towards addressing the crisis. EPIs varied from 150 as very effective to 40 effective on creation of public awareness. Prohibition of social gathering had an EPI of 90 effective and 70 very effective while offering of tax relief had EPIs of 69 effective and 49 very effective thus strong positive perceptions. Creation of economic stimulus packages had EPIs of 101 satisfactory, 52 effective, 44 very effective 
hence, showed positive perceptions towards the response by the two levels of governments in curbing the effects of the double crisis especially the COVID-19 pandemic.

Neutrally at EPI of 89 and 40 on provision of relief food and evacuation of flood victims respectively. Thus, the respondents had divided perceptions on the contributions of the two levels of governments in addressing the phenomena. Evacuation to safer grounds was poorly done and had an EPI of 160 not effective.

\section{Conclusion and Recommendations}

The changes of the levels of the Lake Victoria waters had negative impacts on land use patterns along its shores causing food security challenges in the region. This was occasioned by submergence of land use activities along the shore line up to approximately $294 \mathrm{~m}$ into the land surface. Areas under papyrus reeds and fishing grounds expanded while areas under sand extraction, farming, grazing, beach, trade and tourism decreased. Consequently, food availability in the region was affected due to decline in food production caused by flood. Access to food was threatened by the destruction of transport infrastructure which could facilitate importation of food from other areas. Additionally, the destruction of other income generating activities in the region such as sand extraction and trade denied the residents sources of income needed to access food.

In addition to the ravenous effects of COVID-19 pandemic, the local community experienced a double crisis as majority of them were displaced from their homes. The displaced residents camped together in social institutions like schools and churches against the self-quarantine and anti-social gathering principles to curb the spread of COVID-19 pandemic. Majority of the respondents lost their income generating activities despite the upsurge of prices of commodities. Hence, they responded by reducing and varying the kind of meals they consumed in a day, moving to safer higher grounds and assisting the most vulnerable members of the society. The study found a strong positive perception on the responses by the GoK and CGoHB in handling the COVI-19 pandemic with the Likert's scale SEPI of 381 very effective and 328 effective.

The study recommends the following: Enforcement and adherence to the environmental laws governing settlement and utilization of resources around the riparian areas in order to prevent future destruction of properties and displacement of people. Proactive compliance with warnings and advice from the Meteorological Department concerning hydrological patterns in time rather than waiting for actual occurrence of disasters and then react. Continuation of collective responsibility and philanthropism witnessed during the double crisis period so as to continue solving present crisis and finally, seeking alternative land use activities to replace those destroyed by the back flow and flood.

\section{Acknowledgment}

Glory be to God Almighty who has given me strength, courage and resilience to conduct this study. I wish to acknowledge Dr. Otieno A. Charles for his positive criticism in the development of this study and Mr. Danrage Gikunda from the school of Spatial Planning and Natural Resources, Jaramogi Oginga Odinga University of Science and Technology for his assistance in cartographic part of this study. I would also like to thank all my respondents for their positive cooperation during field work. Finally, much thanks go to the Land Science journal for their assistance in manuscript preparation.

\section{References}

Aloo, P. A. (2002). Effects of climate change and human activities of the ecosystems of Lake Baringo, Kenya. In Odada, E., \& Olago, D. O. (Eds.), The East African Great lakes: Limnology, Palaeo - limnology and Biodiversity (pp 335-347), Kluwer Academic Publishers, Netherlands.

Apunyo, R. (2006). Managing Wetlands with Changing Times-Uganda's Experience. Makerere Institute of Social Research.

Araoye, M., Olarinkoye, A., \& Ajiboye, A. O. (2016). The effects of transportation system on food marketing and security in Nigeria. https://doi.org/10.13140/RG.2.15075.0488

Aseto, O., \& Ong'ang'a, O. (2003). Lake Victoria (Kenya) and its environs: Resource, Opportunities and Challenges. Africa publishing House, Kendu Bay, Kenya.

Capital Weather Gang Analysis (2019). Retrieved August 9, 2020 from www.washingtonpost.com

Crisis Looms as Lake Victoria Shrinks at alarming (2006). Retrieved September, 29, 2019 from https://www.nation.co.ke/life

Desiccation of Aral Sea (n.d). Water Management Disaster in the Soviet Union. Retrieved from www.ciesin.org/docs/006-238/0. 
Food and Agricultural Organization (FAO). (2012). Global Food Security 2030.

Gaybullaev, B., Chen, S. C., \& Gaybullaev, D. (2012). Changes of the water volume of the Aral Sea after 1960. Appl. Water Sci., 2, 285-291. https://doi.org/10.1007/s13201-012-0048-z

Kite, G. W. (1982). Analysis of Lake Victoria levels. Hydrol, Sci. J., 27, 99.

LVBC. (2006). Special report on declining water levels of Lake Victoria. EAC Secretariat, Arusha, Tanzania, p. 15.

Mkhawani, K., Motasi, S. A., Mabapa, N. S., \& Mbhenyane, X. G., et al. (2016). Effects of rising food prices on house Hold food security amongst female headed households in Runnymede village, Mopani District, South Africa. South African Journal of Clinical Nutrition, 26.

Nagoli, J., Green, E., Wapulumuka \& Chiwona, L. (2018). Coping with the Double Crisis: Lake Chilwa recession and the Greater Depression on Chisi Island in colonial Malawi. https://doi.org/10.1007/510745-9882-1

Nicholson, S. E. (1988). Historical fluctuations of Lake Victoria and other lakes in the Northern Rift Valley of East Africa. In Lehman, J. T. (Ed.), Environmental change and Response in East African lakes (pp7-35). Kluwer, Dodrecht.

Nile Basin Initiative (NBI). (2020). Unprecedented rise in water levels of Lake Victoria. Retrieved from October 10, $2020 \mathrm{https}: / / w w w . n i l e b a s i n .0 \mathrm{rg} /$ about-nile-basin/1-the-cours-of-the-river-nile

Obiero, O. K., Philip, O., Raburu, J. B., Okeyo-Owuor \& Elizabeth, A. R. (2012). Community perceptions on the impacts of recession of Lake Victoria waters on Nyando wetlands. https://doi.org/10.5897/SRE11.324.

Ogola, J. S., Abira, M. A., \& Awuor, V. O. (Eds.). (1997). Potential impacts of climate change in Kenya. Climate Networks in Africa (CNA), Nairobi, Kenya.

Okonga, J. R., Sewagudde, S. M., Mngodo, R. J., Sangale, F. D., Mwanuzi, F. L., \& Hecky, R. E. (2005). Water balance for Lake Victoria. In Odada E. et al. (eds.), Proceedings Vol. II of the $11^{\text {th }}$ World Lake Conference (Vol. 2, pp. 47-56). $31^{\text {st }}$ Oct. $-4^{\text {th }}$ Nov. 2005, Nairobi, Kenya.

Otieno, J., \& Otieno A. C. (2019). Effects of piers on water recession on the Southern shores of Winam Gulf, Homa- Bay County, Kenya. https://doi.org/10.305060/Is.vln1p29.

Rehm, C. D., Monsivais, P., \& Drewnowski, A. (2011). The quality and Monetary Value of diets consumed by adults in the United States. American Journal of Clinical Nutrition, 1333-1339.

Republic of Kenya, Vision 2030: Second Medium Term Plan 2017-2017.

Robi, S. (News Reporter). (2020, October, $10^{\text {th }}$ ). Swelling of Lake Baringo. [9pm News Bulletin]. Kenya Broadcasting Cooperation, Kenya.

Smith, S. M. (2013). Determining Sample Sizes: how to ensure you get the correct sample. Retrieved December 13, 2020 from https://www.qualtrics.com/blog/determining -sample-size/

Steinman, A., Harvens, K., \& Horning, L. (2003). The managed recession of Lake Okeechobee, Florida. Integrating Science and Natural Resource Management Conservation Ecology, 6(2), 17.

Tulare Lake Basin (2019). Retrieved September 22, 2019 from https://www.waterreduction.org>Tulare-1

USDA. (2005). Low water levels observed on Lake Victoria. Retrieved November 30, 2020 from www.reliefweb.int/report/kenya/usda-low.

Why Kenya's Rift Valley lakes are going through crisis (2020, August 20 ${ }^{\text {th }}$ ). Retrieved November 29, 2020 from www.aljazeera.com/news.

\section{Copyrights}

Copyright for this article is retained by the author(s), with first publication rights granted to the journal.

This is an open-access article distributed under the terms and conditions of the Creative Commons Attribution license (http://creativecommons.org/licenses/by/4.0/). 